\title{
THE ASSESSMENT OF INTELLECTUAL CAPITAL (IC) IN THE SOUTH AFRICAN CONTEXT - A QUALITATIVE APPROACH
}

\author{
MARIUS DE BEER \\ NEIL BARNES \\ Programme in Leadership Perfomance \\ Rand Afrikaans University
}

\begin{abstract}
The aim of the article is to report on an investigation into IC as portrayed by thought leaders and research groups, against a South African background. An attempt was made to clarify relevant terminology, develop a model and methodology for South African application, and assess the status of IC within the South Africa context through a qualitative methodology using Focus Groups. Results indicated that IC in South Africa is still in the infancy stage. However, models and methodologies developed in other continents could with changes be applied in the South African context.
\end{abstract}

\section{OPSOMMING}

Die doel van hierdie artikel is om verslag te doen oor die ondersoek na Intellektuele Kapitaal (IK) soos voorgestel deur vakkundiges en navorsingsgroepe, teen die agtergrond van die Suid Afrikaanse situasie. 'n Poging is aangewend om tersaaklike terminologie te verklaar, 'n model en metodologie vir Suid Afrikaanse aanwending te ontwikkel, en dit sowel as die status van IK in die Suid Afrikaanse omgewing te ondersoek deur middel van 'n kwalitatiewe metodologie, naamlik fokusgroepe. IK in Suid Afrika is steeds in die kinderskoene. Modelle en metodologieë ontwikkel in ander lande kan egter met aanpassings aangewend word vir aanwending in die Suid Afrikaanse omgewing.

Stewart \& Sveiby (as cited by Bontis, 1998, p.63) wrote that: "Intellectual capital has been considered by many, defined by some, understood by a select few, normally valued by a select few, and formally valued by no one". However, Petty \& Guthrie $(2000$, p.1) claim that stage one has been completed, i.e. raising awareness. The challenge now is to establish research into Intellectual Capital (IC) as a legitimate undertaking, and gather robust evidence of its further development and relevance for competitive advantage.

Corporations devote meticulous attention to the analysis and accounting of tangible assets. But there is no process to measure and analyse investments in knowledge capital. Focus is shifting from individual assets to groups of assets where different types of assets co-operate in the production of value. In an information and knowledge society, the main part of these assets are intangible: this is the intellectual capital - synonym of knowledge capital - embodied in the skills, knowledge and experience of people and in organisational procedures, systems and routines.

To measure IC however requires metrics that are repeatable and quantitatively definable in monetary terms. This calls for methods that are independently verifiable. Knowledge capital has also become the financial community's favourite rationalisation for the stratospheric prices of some stocks. In most markets the ratio of Intellectual Capital to Financial Capital is growing rapidly, with the result that organisations dispose of a stock of intangible assets e.g. sales of shares, which far outstrips the tangible. Governments are also increasingly taking interest in IC, which becomes evident through all the sponsored research, and expected external financial reporting regulations to be introduced to promote transparency. (Bontis, 1998, p.64; Balancing accounts with knowledge, 1999, pp. 5 and 19; Edvinsson, 2000, p.13; Sveiby, 1998, p.1; Intellectual Capital Accounts, 1997, p.7; Hitt, Ireland, \& Hoskisson, 1999, p.19).

\section{SETTING OF THE PROBLEM}

Traditionally accepted and applied management doctrines do not provide for IC management; in fact traditional accountancy methodologies do not even know how to measure it, resulting in

Requests for copies should be addressed to: $M$ de Beer, Department of Human Resource Management, RAU University, PO Box 524, Auckland Park, 2006 it being ignored or referred to by non-essential terms such as "goodwill". Goodwill however consists of IC plus other intangible assets (Bassi, 1999, p.428)

The need to measure IC, make it visible, and influence the total value (stock price) of an organisation, is especially vital for organisations which are contemplating:

- Listing on the stock exchange

- Issuing shares

- Take-overs

- Mergers

- Alliance formation

- Selling out

- Increasing the value of the organisation

- Ensuring future competitiveness of their company

- Aligning their HR strategy with business strategy

- Gaining transparency of their company's IC and managing it

- Developing of skills and competencies

In order to influence the stock price of a company, its IC must therefore:

- Be identified

- Deliverable (measurable) proof of potential

- Be valued

- Be made visible

Proof of the importance and advantages of addressing IC are in abundance e.g.:

- The Netherlands study (Intellectual Capital Accounts, 1997, p.3) documented both internal and external advantages that IC accounts can generate.

- Companies managing their IC outperformed other companies (Bornemann et al, as cited by Petty \& Guthrie, 2000, p.165).

- PricewaterhouseCoopers (PwC) performed an assessment of the benefits of reporting on intangible assets. They reported a reduction in cost of capital and thus an increase in share price. Increased transparency also inspired confidence among staff and other stakeholders (1999, Balancing accounts with Knowledge, Report PwC, pp.12 and 25).

- The existence of a significant positive relationship of IC with business performance, and those efforts to manage knowledge and develop structural capital, led to higher business performance (Pena, 2002, p.181). 
- "The higher a company's Human Capital Index, the higher its financial performance", according to one of the big HR consulting companies, Watson-Wyatt, who have developed a Human Capital Index attempting to correlate economic value with a set of human resource practices (Stewart, 2001, pp. 309-310).

- The existence of a significant positive relationship of IC with business performance, caused by the organisation's efforts to manage knowledge and structural capital (Bontis et al, 2000, p.85).

- "...a close connection between IC accounts and financial results can be documented' (Intellectual Capital Accounts, 1997, p.18).

- According to Peppard \& Rylander (2001, pp. 226-227), the IC perspective has contributed in the following ways:

$\circ$ Providing a holistic view of the company

- Focussing on value

- Providing a common language

- Providing a basis for developing the understanding of the nature of resources in action

- Enabling a practical rather than conceptual perspective

The importance and relevance of IC, and the necessity to research the phenomena within the South African context became evident from the above. The set goals for this research study were therefore:

- To conduct a literature study in an attempt to identify and confirm all variables and moderators of IC.

- To utilize this knowledge to develop an assessment methodology and framework.

- To assess the status of IC within the South African context.

- To assess the feasibility of the proposed model and methodology.

\section{CURRENT KNOWLEDGE OF THE PROBLEM}

It is impossible to start any study without first identifying thought leaders in the field of IC. Verna Allee (2000, p.19) for example names first of all Karl-Eric Sveiby, who introduced the concept of intangible assets to managers in Northern Europe and Scandinavia in the mid-eighties. Thomas Stewart followed with his article in the Fortune magazine, and later his popular book "Intellectual Capital: The New Wealth Of Nations" in 1997. A number of authors proposed new accounting practices to explain, manage and measure these intangible assets e.g. Kaplan \& Norton with their Balanced Scorecard approach in 1996, and Sveiby \& Edvinsson with their Intellectual Capital methods in 1997. Patrick Sullivan (2000, p.2) mentions as far back as 1980 Hiroyoki Itami's book "Mobilizing Invisible Assets". It is however quite obvious how numbers of publications have progressively increased up to the year 2000. Other thought leaders are Johan \& Göran Roos, Annie Brooking, Gordon Petrash, Baruch Lev, Michael Malone, Nick Bontis and Hubert Saint-Onge.

Methods for the measurement of IC are just as plentiful as the theorists on the subject, which suggests that there is no generally accepted theoretical model for understanding IC (Petty \& Guthrie, 2000, p.160). However, there is an overwhelming consensus as to the need for such instruments. Disagreement however prevails about the use of financial rather than nonfinancial parameters.

Studies, e.g. The Malaysian studies (Bontis et al, 2000); The Danish Trade and Industry Development Council's studies (Intellectual Capital Accounts, 1997); The Netherlands' Ministry of Economic Affairs' studies (Balancing accounts with Knowledge, 1999); The Organisation For Economic Co-operation and Development (OECD) Studies (OECD, 1999); The Spanish companies' "best practices" studies (Sanchez et al, 2000); MAGIC (Measuring and Accounting Intellectual Capital), the European research and development project and QPR's Scorecard (QPR Online, 2002); Intellectual Capital Management
(ICM) Group Study (ICM Group, Inc, 1998); and the Canadian Biotechnology Study (Cumby \& Conrod, 2001, p.265), revealed an increasingly popular classification that divides intellectual assets into three categories i.e.

- Human Capital

- Structural Capital

- Customer Capital

These are viewed from the following perspectives:

- External perspective - forward view in which an assessment of the company's environment and sector plays a role

- Internal perspective - past view in which the assessment of the company's non-valued assets is focussed on.

Methods of measurement are divided into three main categories, namely:

- Input Related (focus on resources)

- Process Related (focus on value adding)

- Output Related (focus on revenue generation).

Additional authors that were studied in order to be able to develop an IC organisational model are depicted in Table 1 (McElroy, 2002, pp. 30-31; Bontis, 2001, pp. 47,49,54 and 56; Stewart, 1997, pp. 226-229; Sveiby, 1998, p.4; Balancing accounts with Knowledge, 1999, p. 9; Guthrie \& Petty, 2000, p.3; Pike \& Roos, 2000, p.10; Aberg \& Edvinsson; 2001, p.7; www.unic.net; M'Pherson \& Pike, 2001, p.248; Allee, 2000, p.19; Low, pp. 256-262).

TABLE 1

IC ASSESSMENT METHODOLOGIES

\begin{tabular}{lll}
\hline Methodology & Author/Concept originator \\
\hline 1 & The Skandia Navigator & Leif Edvinsson \\
2 & IC Map & Mark McElroy \\
3 & Citation-weighted Patents model & Gordon Petrash \\
4 & Tobin's q & James Tobin \\
5 & Intangible Asset Monitor & Karl Erik Sveiby \\
6 & The MVA (Market Value Added) & Stern Stewart \\
7 & EVATM (Economic Value Added) & Stern Stewart \\
8 & The Holistic Value Approach (HVA) & ICS \\
9 & The IC-Index & Göran Roos \\
10 & The Technology Broker & Annie Brooking \\
11 & The IC RatingTM & Aberg and Edvinsson \\
12 & UNIC-concept & www.unic.net \\
13 & Inclusive Value Methodology - IVMTM & Professor Phillip M'Pherson \\
$\mathbf{1 4}$ & Value Domains & Verna Allee \\
$\mathbf{1 5}$ & Value Creation Index (VCI) & Cap Gemini Ernst and Young's \\
& Centre for Business Innovation \\
$\mathbf{1 6}$ & Value Added Intellectual Coefficient & Pulic \\
(VAICTM) & The Knowledge Value-Added (KVA) & Drs. Thomas J. Housel and \\
\hline & & Valerie Kanevsky \\
\hline
\end{tabular}

Figure 1 depicts the IC determinants derived from the above information.

With regards to the Figure 1, Stewart (1997, p.101) defines IC as "the intellectual material - knowledge, information, intellectual property, experience - that can be put to use to create wealth". The Intellectual Capital Management (ICM) gathering (Harrison \& Sullivan, 2000, p.34) defined IC as "knowledge that can be diverted into profit". Bassi (1999, p.424) summarized the above saying that IC is knowledge that is of value to an organisation and can be segmented into three sub-categories: Human Capital, Structural Capital, and Customer Capital. From the above, the author came to the conclusion that IC represents the experienced difference between the market value of a company and the 
balance sheet of a company, comprising of strategic intangible assets i.e. data, information, knowledge, experience and intellectual assets, that can be diverted into profit. IC therefore represents the potential of a company to create and extract value through its intangible assets.

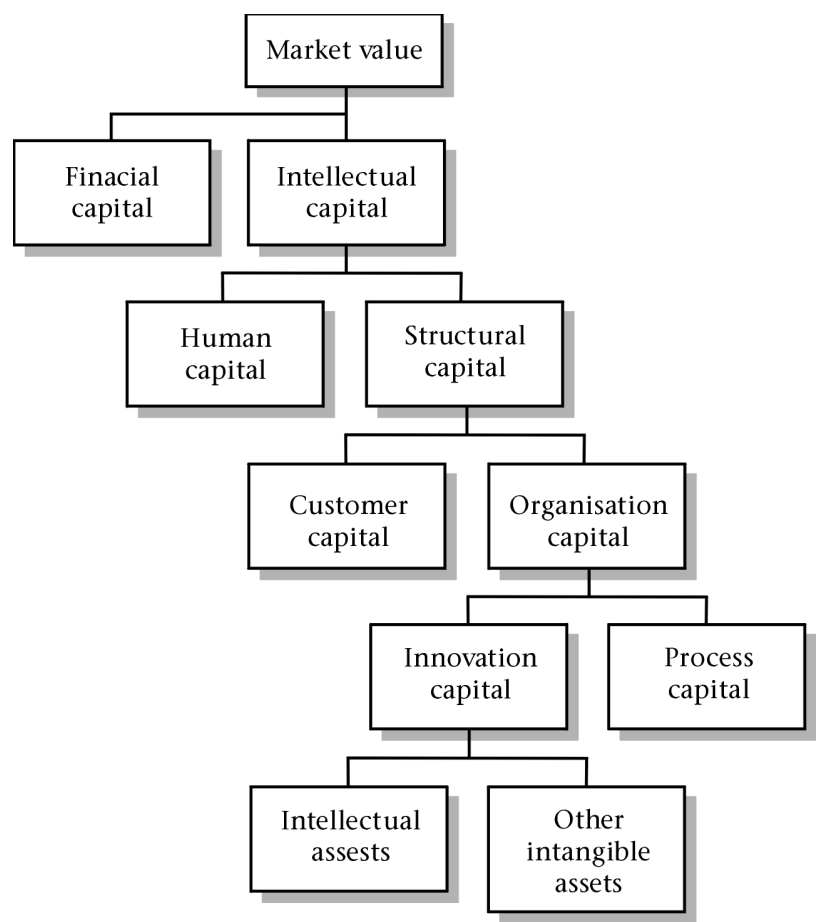

Figure 1: IC Determinants

A model based on the previous discussion is indicated in Figure 2.

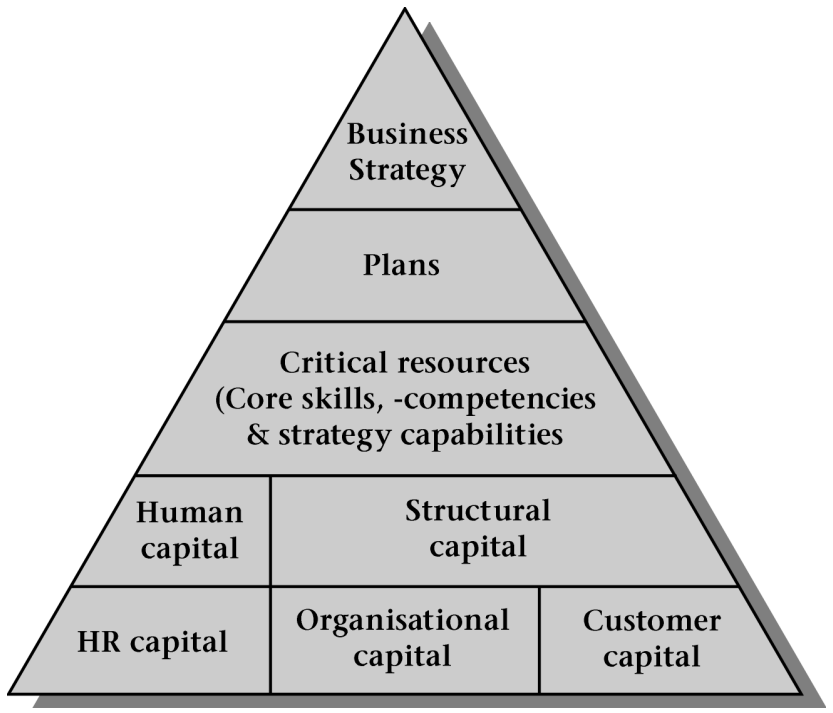

Figure 2: Provisional IC Model

The purpose of this study has been to create an organisational framework (model) of IC. Out of the literature surveyed, a model is suggested (See Figure 2). The major organisational dimensions would be Human Resources Capital ((Individual Knowledge, Skills, Ability, Attitudes i.e. Technical, Analytical, Interpersonal, Conceptual.), Organisation Capital (Internal: Intellectual property e.g. Patents, Copyrights and Trademarks, Information systems, Networking Systems, Infrastructure assets, Management philosophy, Corporate culture, Management processes, Financial relations) and Customer Capital (External relationships: Brands, Customers, Customer loyalty, Company names, Franchising agreements, Distribution channels, Business collaborations, Licensing agreements and Favourable contracts.)
Once the dimensions for measuring IC were defined, a methodology to measure IC was developed (See Figure 3):

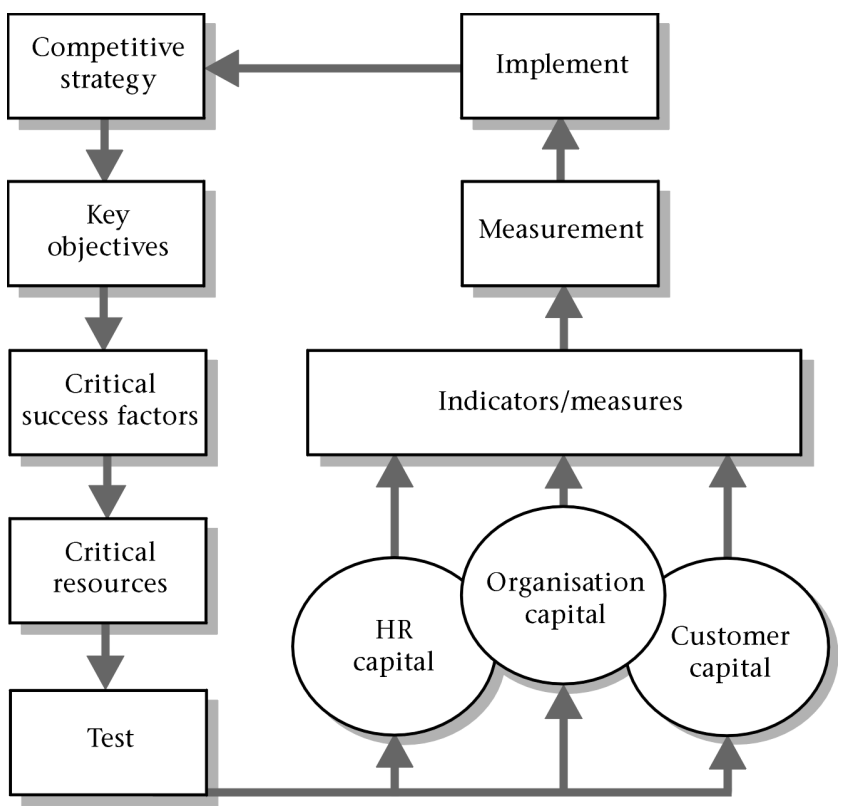

Figure 3: IC Assessment methodology

The suggested process for measuring IC is as follows:

- Do proper strategic planning

- Including a thorough environmental analysis, which is essential when comparing (benchmarking) information e.g. competitor information

- Develop IC strategy and plan e.g. the reasons and purpose of IC measurement (needs and requirements)

- Identify/define IC

- Through the normal process of Key Performance Areas and Critical Performance Indicators, identify critical resources i.e. core competencies that are linked to the competitive strategy of the organisation's strategy and plan.

- Test the relevance of each critical resource/core competency by assessing the value that they add. This can be established by asking the following questions.

- Adding value

Does the core competence/critical resource offer a substantial benefit for the majority of customers or offer a substantial cost saving to the company for the foreseeable future, which makes us different from the competition and therefore creates demand?

- Competitiveness

Do the minimum of competitors share this particular core competence/critical resource, in which we show superiority and invest substantially more time and money in, that is visible through our trade articles, patents, trademarks etc.?

- Potential

Is this core competence/critical resource directly related to the increasing demand for our products/ services, and allow the development of new products and services and entrance to new markets in the future? Are there no economic threats (customers, suppliers, competitors) or social threats (regulatory and social), which will adversely affect the use of this competence/resource?

- Sustainability

Is this core competence/critical resource scarce in our industry and it would require considerably investments in time and/or money for competitors to master? Are components of the competence/resource protected by patents, trademarks and other legal measures, and a combination of a number of intangibles such as skills, knowledge, processes, and 
corporate culture, thus making it difficult to copy, and not obtainable through acquisition or from other outside sources?

- Risk

Are the group of people that possess the core competence, the technology and IT systems, and the endowments this core competence depends on vulnerable? Are the values and norms on which this competence is built under pressure, and the primary and management processes, which this competence uses unreliable?

- Develop measures for critical resources, core competencies.

- Measure.

- Populate all the above in the IC Framework.

- Measure by describing the current situation or the "As is".

- Identify/analyse the gap with the ideal situation or "To be" and plan.

- Implement

- Create and maintain competitive advantage.

- Execute plan.

- Invest in IC i.e. employees.
The above methodology could be applied in practice by creating the following framework.

Table 2 combines the IC dimensions identified and the IC measurement process as follows: As part of the strategic planning process, the mission, key objectives and critical success factors should be developed/identified. This forms the basis of identifying critical resources/core competencies in each of the IC dimensions. Once the critical resources/core competencies are identified, the value contribution is assessed through the "value test". Relevant performance indicators/measures are then identified and used to create a picture of the current situation and the desired situation (gap analysis).

\section{METHOD}

The following questions were developed to address the specific goals of this study with regard to the assessment of IC in the South African context.

- What is the current status in South Africa with regard to IC and IC measurement?

- What is the extent of demand for IC reporting in the South African market?

TABLE 2

IC MEASUREMENT FRAMEWORK

Mission:

Key objectives:

Critical success factors:

Critical resources

IC Measurement

Core skills,

Competencies and strategc capabilities
Value contribution (Competitiveness Sustainability,

Potential, Risk)
"As is" Current situation"
"To be" Measures
Human resources

Capital

(Individual Knowledge,

Skills, Ability, Attitudes i.e.

Technical, Analytical,

Interpersonal, Conceptual.)
Organisational

Capital

(Internal: Intellectual

property e.g. Patents

Copyrights and Trademarks,

Information systems, Networking

Systems, Infrastructure assets,

Management philosophy,

Corporate culture,

Management processes and

Financial relations)

\footnotetext{
Customer

Capital

(External relationships: Brands,

Customers, Customer loyalty,

Company names, Franchising

agreements, Distribution

channels, Business collaborations,

Licensing agreements and

Favourable contracts)
} 
- Within a South African organisation, who is best positioned to measure and manage IC?

- What are the current and anticipated effects of reporting IC in South Africa (competitive advantage)?

- What are the current problems, difficulties and/or barriers concerning the introduction of IC in South Africa?

- Is gathering information on IC feasible from a cost/benefit perspective?

- What are the determinants that affect IC within companies?

- What is the most effective methodology for assessing IC within companies?

- How might current methods of measuring IC be improved?

- What is this study's relevance to the South African context?

To ensure that the validity of the research findings increased, the stages, as proposed by Mouton \& Marais (1992, p.25) were followed:

- Choosing of the research subject or theme

- Formulation of the research problem

- Conceptualisation and operationalisation of the problem

Focus group interviewing is a qualitative data gathering method with a long history in research, but has been under-used. Qualitative measures are typically judgement-based and used when the item to be measured does not lend itself to quantifiable measurement. Focus groups research involves organised discussion with a selected group of individuals to gain information about their views and experience of a topic. One qualitative study on IC used focus groups to provide an additional method for obtaining more detailed data. Each group consisted of seven to ten people (Miller et al as cited by Brennen \& Connel, 2000, p.235)

TABLE 3

FOCUS GROUP INTERVIEW GUIDE

\begin{tabular}{|c|c|c|}
\hline & Type of Question & Question \\
\hline 1 & Opening question & $\begin{array}{l}\text { What is the current status in South Africa } \\
\text { with regard to IC and IC Measurement? } \\
\text { What is the extent of demand for IC } \\
\text { reporting in the South African market? }\end{array}$ \\
\hline 2 & Introductory question & $\begin{array}{l}\text { Within a South African organisation, who is } \\
\text { best positioned to measure and manage IC? } \\
\text { What are the current and anticipated effects } \\
\text { of reporting IC in South Africa (competitive } \\
\text { advantage)? }\end{array}$ \\
\hline 3 & Transitional question & $\begin{array}{l}\text { What are the current problems, difficulties } \\
\text { and/or barriers concerning the introduction of } \\
\text { IC in South Africa? } \\
\text { - Is gathering information on IC feasible from a } \\
\text { cost/benefit perspective? }\end{array}$ \\
\hline 4 & $\begin{array}{l}\text { Key questions - seen } \\
\text { against the } \\
\text { background of the } \\
\text { proposed model and } \\
\text { methodology }\end{array}$ & $\begin{array}{l}\text { What are the determinants that affect IC } \\
\text { within your companies? } \\
\text { - What is the most effective methodology } \\
\text { for assessing IC within your companies? } \\
\text { - How might current methods of measuring IC } \\
\text { be improved? }\end{array}$ \\
\hline 5 & Ending question & $\begin{array}{l}\text { - What is this study's relevance to the South } \\
\text { African context? }\end{array}$ \\
\hline
\end{tabular}

The present study utilised focus groups to verify and add to the exploration in the process of developing an IC model and measurement methodology. The participants were handpicked according to specified criteria. The author chose a size of between eight and twelve participants, and the three groups each contained eight, eleven and ten persons. The decision on the number of groups was influenced by two factors i.e. availability of participants and their relevance to the study. Six groups were aimed for of which three were realised. As was evident because of duplication and new information gathered by the second and third focus groups, three sessions proved to be sufficient. Every effort was made to ensure attendance through personalisation of invitations and motivation, however only about half of the people that confirmed, turned up. The interview venue was also selected based on convenience. An interview guide was developed using questions, which were carefully selected and phrased prior to the focus group interviews in order to elicit the maximum amount of information (See Table 3). The concept was defined clearly with identified critical questions, based on the research questions. The concepts were broad and limited to five phases. Questions were also from more general to more specific (the funnelling process) to enable all the participants to "grow" into the subject, putting them at ease and opening their minds to the subject. In order to gain an understanding of the critical issues, specific follow-up questions and probing were used during the interview. Additional information was asked from the interviewees to support information gathered during the focus group interviews to enable more in-depth and meaningful evaluation of the proposed IC model and methodology.

\section{RESULTS}

The focus groups revealed that IC and IC measurement in South Africa is still in its infancy stage and that companies that do attend to this phenomenon are the exception. The short-term viewpoint of financial capital as the only capital of value is still solidly intact. Some audit firms are doing research on how to report by means of notes in financial reports. The big consulting firms have the knowledge and applications internationally obtained. Other variables also play an enormous role in South Africa. It is believed that companies understand the IC concept in different ways, which contributes to the confusion in determining the real definition of IC and IC Measurement. Models and concepts do not cater for the South African conditions but are based on models build abroad.

The demand for IC reporting is rather insignificant, although a definite interest exists in IC and sharing IC. This need tends to be more significant in knowledge-based companies. Ignorance also plays a definite role. Companies are not aware of the specific topics/issues, how to define measurement, what to measure, and how to present the results. Where there is a need, clients are definitely willing to pay to satisfy it. The suspicion also exists that IC will become a form of "flavour of the month". A need will be for experts to satisfy the transparency demand and assist with transformation and the transfer and development of knowledge and skills.

The question on who would be best positioned to measure and manage IC was quite controversial. Focus group participants nominated almost all the functional managers. All the focus groups however agreed that the accountability should lie with the $\mathrm{CEO}$, but IC should be incorporated in the performance agreements of all managers. The necessity to involve an external party for objectivity purposes was also stressed.

The general view was that IC and IC reporting can have a considerable impact on South African businesses. Its use will lead to IC identification, gap analysis, and more focus on the human capital in most business enterprises. The focus may eventually shift to the non-financial/physical assets of companies, leading to an increase in competitiveness. Measuring IC will also bring South Africa in line with world practices and possible legislation in future. The disadvantages as mentioned should, however, not be ignored e.g. cost of IC implementation and its vulnerability.

The current problems, difficulties and/or barriers concerning the introduction of IC in South Africa are first of all the lack of interest/ understanding of the concept. IC is still relatively an unknown in South Africa, and difficult to measure. Third world issues e.g. survival and basic skills are perceived more important than intangible assets at this stage. The unfriendly view towards qualitative measurement, the non-uniformity and lack of legislation around the issue also has an effect on IC measurement. Care should however be taken not to generalise about the above, because evidence of the opposite exists. 
The gathering of information on IC from a cost/benefit perspective will be feasible on the long term - as are most initiatives, provided there is executive commitment and it is structured as an integrated part of an IC management program. This again will only happen when companies start to understand and apply IC correctly. The biggest impact may be in the IT and Service industry, which feels that they can afford the "luxury". Value can be added in any industry that employs Human Capital and regards their employees as their "most valuable possession".

The determinants that affect IC in companies in the South African environment are mainly the same as projected by the literature reviewed i.e. structural, human and organisational. The relevance of IC for strategy in the process was especially noted. Culture and aspects like the social environment and politics also play a major role in influencing IC.

Methodologies for assessing IC are generally unknown. Those linked to known models e.g. the Value Chain; the Excellence Model and the Balanced Scorecard were considered as possible assessment methodologies, linked to strategy and performance. Adding a risk and potential test was also mentioned as an improvement to most available methodologies. The model and methodology as proposed by the authors were in principle accepted.

Methods to measure IC in South Africa are generally unknown. Ideally methods must however be standardised and internationally accepted, although one would find that the more progressive enterprises would use it as a management focus to improve performance. The improvement on current methods proposed was to simplify it for South African conditions. The framework suggested by the author was in general accepted.

As far as this study's relevance to the South African context, it was in general the opinion of the different focus groups that it will create awareness of IC and it could make an academic contribution and stimulate further research.

Based on the suggestions made by the focus groups, the following changes were made to the IC model.

- The position of IC strategy within the proposed model was made more visible.

- The depictions of the categorisation of the elements of IC were not done by means of definite partitions e.g. lines, to indicate interrelationships and interactivity.

- Financial Capital was included in the IC model

- The role of the external environment was emphasized more.

The focus groups in general supported the proposed assessment methodology (process). The third focus group was specifically impressed with the value test, i.e. the test to assess whether the specific IC resource/capability definitely adds value, which forms part of the methodology.

The only suggested changes to the IC assessment worksheet as proposed in Table 2 were the use of the terms "current situation" and "ideal situation" instead of the terms "as is" and "to be".

Important to note is the number of industries represented by the participants of the focus groups i.e. Construction, Consulting, Education, Financial/banking/insurance, Food, Health/ Pharmaceutical, IT/TC, Manufacturing/Engineering, Mining, Power generation, Nuclear Energy, Petro-chemical, Public Service, Public Service, Research, Rubber, Telecommunication/Electronics and Transport. Table 4 represents specific feedback from the industries. From the sessions it became evident that IC is still in its infancy in companies in South Africa, with some interest and movement occurring in the Banking, Cellular phones, Petro-chemical and Transport industries.
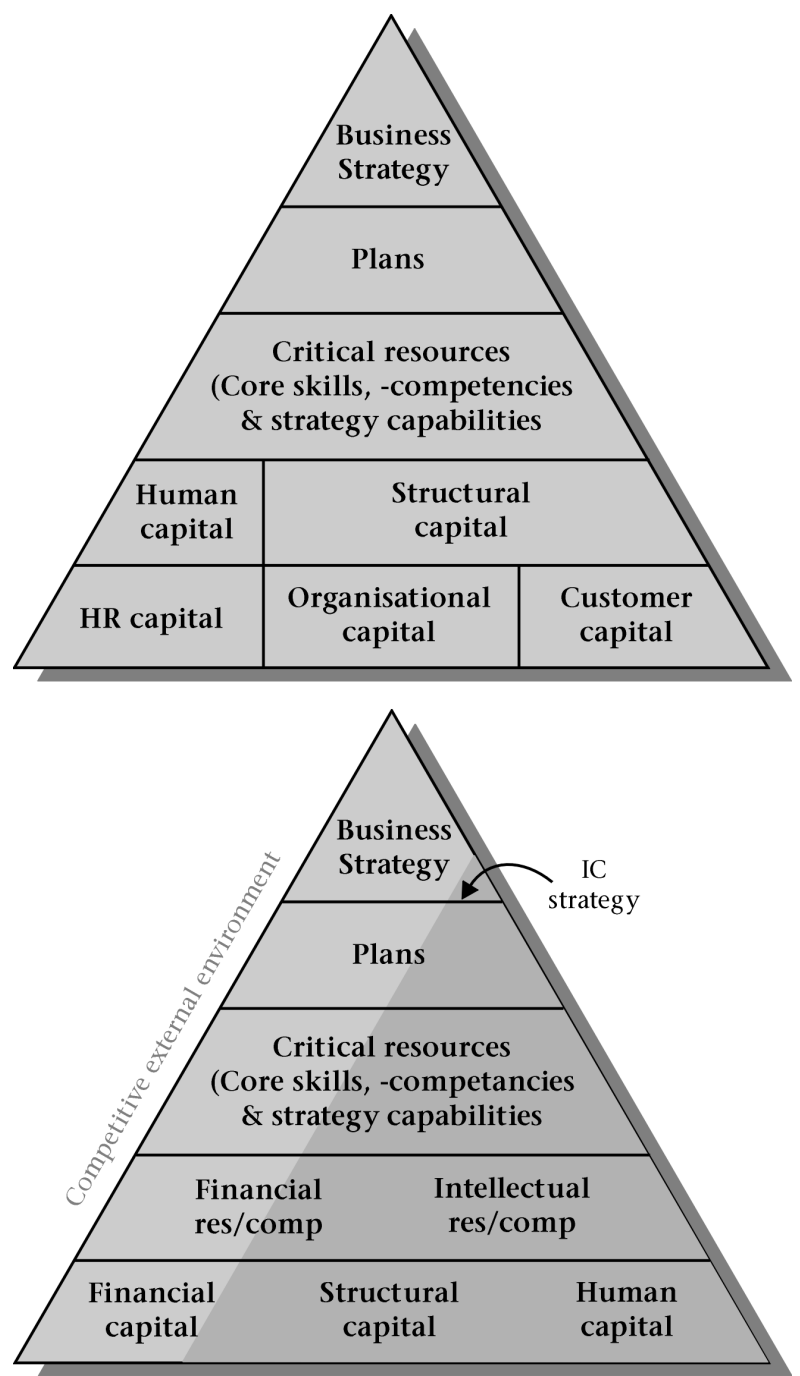

Figure 4:Comparison of IC Models.

TABLE 4

FEEDBACK BY INDUSTRY

\begin{tabular}{|c|c|c|}
\hline & Industry & Specific Comments \\
\hline 1 & $\begin{array}{l}\text { Construction/Food/ } \\
\text { Power Generation/ } \\
\text { Manufacturing/ } \\
\text { engineering/Mining/ } \\
\text { Rubber }\end{array}$ & $\begin{array}{l}\text { Not regarded as problem. Majority of } \\
\text { employees are on lower skilled/artisan level. } \\
\text { Work processes and procedures are described } \\
\text { in detail }\end{array}$ \\
\hline 2 & Consulting & $\begin{array}{l}\text { IC is major problem. Companies are required } \\
\text { to capture processes and methodologies to } \\
\text { ensure continuation/reusability. }\end{array}$ \\
\hline 3 & Education/Research & $\begin{array}{l}\text { Not attended to at all. They believe IC is } \\
\text { captured in educational books. }\end{array}$ \\
\hline 4 & $\begin{array}{l}\text { Financial/banking/ } \\
\text { insurance }\end{array}$ & $\begin{array}{l}\text { The major financial institutions are attending } \\
\text { to the phenomena. }\end{array}$ \\
\hline 6 & Health/Pharmaceutical & Not attended to at all. \\
\hline 7 & $\begin{array}{l}\text { IT/IC/ } \\
\text { telecommunications/ } \\
\text { electronics }\end{array}$ & $\begin{array}{l}\text { IC is a major concern, however not yet } \\
\text { addressed as supposed to. }\end{array}$ \\
\hline 8 & Nuclear Energy & No comments. \\
\hline 9 & Petro-chemical & $\begin{array}{l}\text { Major organisation also attending to IC, more } \\
\text { focus however on Intellectual Property. }\end{array}$ \\
\hline 10 & Public Service & $\begin{array}{l}\text { Although a major problem with regard to } \\
\text { brain drain, generally not attended to. }\end{array}$ \\
\hline 11 & Transport & $\begin{array}{l}\text { Major organisation just starting to attend } \\
\text { to IC. }\end{array}$ \\
\hline
\end{tabular}




\section{CONCLUSION}

Through the process of studying thought leaders' and available research, as well as developing a proposed model and methodology on IC and testing it through the use of focus groups, the author concluded that IC is still in its infancy stage in South Africa, if measured against the development thereof in other countries. Most IC models and theories were basically developed around 2000 and there are still a lot of issues to be clarified and simplified, especially within the South African context.

Although an issue is being made about semantic differences between words like measuring, calculating, evaluating and assessing, the authors are of the opinion that measurement is the generic word encapsulating the most important aspect i.e. comparing something against a standard, whether qualitative or quantitative, specific or benchmarked. The difference between book value and market value is another heated topic. It seems however that IC is very similar to (or interchangeable with) intangible assets, core competencies and goodwill. Comparing IC management and Knowledge management suggests that the latter creates IC, which influences value or profit.

The most common categorisation of IC is:

- Human Capital such as individual knowledge, skills, abilities and attitudes, which are either technical, analytical, interpersonal or conceptual.

- Organisational Capital such as intellectual property (patents, copyrights and trademarks), information systems, networking systems, infrastructure assets, management philosophy, corporate culture, management processes and financial relations. Intellectual Property appears to be a subset of Intellectual assets, which is a subset of IC.

- Structural Capital relates to brands, customers, customer loyalty, company names, franchising agreements, distribution channels, business collaborations, licensing agreements and favourable contracts.

The depiction of the above categories in a hierarchical format does not give justice to fact that the dimensions of IC are interrelated and interdependent.

It was also clear from the literature research that the popular methodology of obtaining information by means of a framework can be applied with success with the measurement of IC. This previously lead to the discovery of the major influence the Balanced Scorecard had on the development of IC and IC methodologies, as well as the problematic use of other frameworks e.g. the value chain, Business Excellence Model, and ISO 9002 for measuring IC.

IC is a strategic issue for which a CEO of a company should be accountable, supported by his executives. It is also at this level that the reasons and methodology for the management of IC must be clarified. Strategic terminology e.g. key objectives, critical success factors, and critical resources/ core competencies, play a major role in identifying IC. An absolutely compulsory activity is the test of confirming the strategic value of the IC asset through the measurement of added value, competitiveness, sustainability, potential and risk. To keep context, both financial and non-financial measures should be assessed.

The meaningfulness of qualitative research has impressed the authors. The amount of relevant information that would never have been accumulated by a questionnaire, plus the amount of control available using the Focus Groups, supports this fact.

The information obtained from the focus groups compared well with the OECD study results, the major difference revealed was in the magnitude or level of current knowledge about the subject in the different hemispheres of the world. In summary, IC in South Africa has still a long way to go and there are still a lot of issues to be addressed that will impact on the successful introduction of the concept in South Africa. The whole study indicated what was later on proved to be the norm, a general ignorance of IC in South Africa and what it entails.

The authors' experience with the subject led to the following recommendations: Firstly, to address the issue of ignorance, tertiary institutions should cover IC in their syllabuses, and see to it that some research is directed towards IC, and articles published. Secondly, researchers/authors should focus on the simplification and standardisation of terminologies and methodologies. Thirdly special focus could be given to the difference or relevance of IC between 1st and 3rd world countries. Last but not least qualitative research should also be promoted as a valid and reliable information gathering method.

\section{REFERENCES}

Aberg, D. \& Edvinsson, L. (2001). The IC multiplier and importance of structural capital. A first investigation of enablers shaping intellectual capital. 1-26. New York University, Stern School of Business.

Allee, V. (2000). The value evolution. Addressing larger implications of an intellectual capital and intangibles perspective. Journal of intellectual capital, 1 (1), 17-32, МСB University Press.

Balancing accounts with knowledge. Pilot Project by the ministry of economic affairs, The Hague, October 1999.

Bassi, L.J. (1999). Measuring knowledge management effectiveness. Harnessing the power of intellectual capital. Knowledge management yearbook, 1999-2000, J.W. Cortada and J.A.Woods, Butterworth-Heineman

Bontis, N. Keow, W.C.C. \& Richardson S. (2000). "Intellectual capital and business performance in Malaysian industries". Journal of intellectual capital, 1 (1), 85-100, MCB University Press.

Bontis, N. (2001). Assessing knowledge assets: a review of the models used to measure intellectual capital. International Journal of Management Reviews, 3 (1), 41-60.

Bontis, N. (1998). Intellectual capital: an exploratory study that develops measures and models. Management Decision, 36 (2), 63-76, MCB University press.

Brennan, N. \& Connell, B. (2000). Intellectual capital. Current issues and policy implications. Journal of Intellectual Capital, 1 (3), 206-240, MCB University Press.

Cumby, J. \& Conrod, J. (2001). Non-financial performance measures in the Canadian Biotechnology Industry. Journal of Intellectual Capital, 2 (3), 261-272, MCB University Press.

Edvinsson, L. 2000. Some perspectives on intangibles and intellectual capital (2000). Journal of intellectual capital, 1 (1), 12-16, MCB University Press.

Guthrie, J. \& Petty, R. (2000). Intellectual capital: Australian annual report practices. Journal of intellectual capital, 1 (3), 241-251, MCB University Press.

Harrison, S. \& Sullivan, P.H. (2000). Profiting from intellectual capital. Journal of intellectual capital, 1 (1), 33-64, МСB University Press.

Hitt, A., Ireland, R.D. \& Hoskisson, R.E. (1999). Strategic management - competiveness and globalisation (concepts and cases). Third Edition. South Western College Publishing Company. (ITP). Cincinnati.

ICM Group, Inc, (1998). "What are companies currently measuring?". http://www.icmgroup.com/.

Intellectual Capital Accounts. Reporting and managing intellectual capital. The Danish Trade and Industry Development Council, Copenhagen, May 1997.

Low, J. (2000). The value creation index. Journal of intellectual capital, 1 (3), 252-262, MCB University Press.

McElroy, M.W. (2002). Social innovation capital. Journal of Intellectual Capital, 3 (1), 30-39, MCB University Press.

Mouton, J. \& Marais, H.C. (1992). Basiese begrippe. Metodologie van die geesteswetenskappe. RGN Uitgewers. Pia. 
M'Pherson, P.K. \& Pike, S. (2001). Accounting, empirical measurement and intellectual capital. Journal of Intellectual Capital, 2 (3), 246-260, University Press.

OECD. (1999). Symposium on measuring and reporting intellectual capital: Experience, issues, and prospects. An international symposium 9-11 June, Organised by the OECD with the Netherlands Ministry of Economic Affairs and Ministry of Education, Culture and Science and the Nordic Industrial Fund. Retrieved from (http://www.oecd.org/ dsti/sti/industry/indcomp/act/Ams-conf/symposium. htm), August 2002.

Pena, I. (2002). Intellectual capital and business start-up success. Journal of intellectual capital, 3 (2), 180-198, MCB University Press.

Peppard, J. \& Rylander, A. (2001). Leverage intellectual capital at ApiON. Journal of intellectual capital, 2 (3), 225-235, MCB University Press.

Petty, R. \& Guthrie, J. (2000). Intellectual capital literature review. Measurement, reporting and management. The Journal of intellectual capital, 1 (2), 55-176, MCB University Press.
Pike, S. \& Roos, G. (2000). Intellectual capital measurement and holistic value approach (HVA). Works Institute Journal (Japan), 42, Oct - Nov, www.works-i.com.

QPR Online. Retrieved from http://www.qpronline.com/ cgi-bin/qpr/qpr.exe? QPRPORTALand* prmavandFMT= candkPbM65uIsW23 BYnil9r065uIs WYDBIm MivqYOMTbqK., August.

Sanchez, P., Chaminade, C. \& Olea, M. (2000). Management of intangibles. An attempt to build a theory. Journal of Intellectual Capital, 1 (4), 312-327, MCB University Press.

Stewart, Thomas A. (1997). Intellectual Capital: The new wealth of nations, Doubleday Dell Publishing Group, New York, NY.

Stewart, Thomas A. (2001). The wealth of knowledge. Intellectual capital and the twenty-first century, Nicholas Brealey Publishing, London.

Sullivan, P.H. (2000). How to convert intangible corporate assets into market value, 238-244, Wiley.

Sveiby, K. (1998). Measuring intangibles and intellectual capital - An emerging first standard, internet version, August 5.

www.unic.net. Retrieved August 2002. 